ISSN. 2775-4324 (Online)

Journal of Physical Activity and Sports

Volume 2, Nomor 3, Desember 2021, 288-296

Journal of Physical Activity and Sports

\title{
Analisis Pembelajaran Penjasorkes Melalui Media Daring Terhadap Hasil Belajar Kognitif Passing Atas Siswa Kelas Xi SMA Negeri 3 Pati
}

\author{
Mila Anggraheni Puspitasari ${ }^{1}$, Tubagus Herlambang ${ }^{2}$, Buyung Kusumawardhana ${ }^{3}$ \\ ${ }^{123}$ Universitas PGRI Semarang. Jl. Gajah Raya No.40, Semarang \\ Anggrahenimila18@gmail.com
}

Received: 22 April 2021; Revised: 28 April 2021; Accepted: 24 Desember 2021

\begin{abstract}
The background to the problem in this study was that during the Covid-19 pandemic, teachers had difficulty providing the online learning process. During this online learning the KKM score for physical education and health services becomes 75 . Students are required to be able to take a KKM score above the KKM 75 to complete it. 36 students from the class that can be used as samples have difficulty understanding the Cognitive aspects of Passing on Volleyball Class XI IPA 3 SMAN 3 Pati students in physical education learning through online media. Limited time and obstacles on the internet make student learning outcomes not optimal, so there needs to be improvements in online learning at SMAN 3 Pati. The formulation of the problem in this study is the difficulty of students understanding the cognitive aspects of upper-pass learning. The purpose of this study was to determine that online media can improve the cognitive learning outcomes of class XI students of SMAN 3 Pati. The research method used is descriptive quantitative research method with the One-Shot Case Study approach, the sample of this study was the students of class XI IPA 3 SMAN 3 Pati using purposive sampling technique. The data analysis method used paired sample-t-test with a significant level of 5\%. The results of the research of 36 students of class XI IPA 3 (Upper Passing) showed that there was an increase in the results of learning over passing through online learning. The increase in the results of learning over passing was $11 \%$. This study also uses a questionnaire to find out what students think about online learning. The conclusion of this research is that the use of online media can help students in learning over passing through online learning at SMAN 3 Pati.
\end{abstract}

Keywords: Online learning, learning outcomes, volleyball

\begin{abstract}
Abstrak
Latar belakang masalah pada penelitian ini yaitu dimasa pandemi Covid-19 guru kesulitan dalam memberikan proses pembelajaran daring. Selama pembelajaran daring ini nilai KKM penjasorkes menjadi 75. Siswa dituntut untuk bisa menempuh nilai KKM diatas KKM 75 untuk bisa tuntas. 36 siswa dari kelas yang dapat di jadikan sampel mengalami kesulitan dalam memahami aspek Kognitif Passing Atas Bola Voli Siswa Kelas XI IPA 3 SMAN 3 Pati pada pembelajaran penjasorkes melalui media daring. Terbatasnya waktu dan hambatan dijaringan internet membuat hasil belajar siswa tidak maksimal, sehingga perlu adanya perbaikan dalam pembelajaran daring di SMAN 3 Pati. Rumusan masalah pada penelitian ini adalah sulitnya siswa memahami aspek kognitif pada pembelajaran pasing atas. Tujuan penelitian ini untuk mengetahui media daring dapat meningkatkan hasil belajar kognitif siswa kelas XI SMAN 3 Pati. Metode penelitian yang digunakan yaitu metode penelitian deskriptif kuantitatif dengan pendekatan One-Shot Case Study,sampel penelitian ini adalah siswa kelas XI IPA 3 SMAN 3 Pati menggunakan sampel teknik sampling purposive. Metode analisis data menggunakan uji paired sample-t-test dengan taraf signifikan 5\%, hasil penelitian dari 36 siswa kelas XI IPA 3 (Passing Atas) diketahui bahwa adanya peningkatan hasil belajar passing atas melalui pembelajaran daring. Kenaikan hasi belajar passing atas sebesar $11 \%$. Penelitian ini juga menggunakan angket untuk mengetahui pendapat siswa mengenai pembelajaran daring.
\end{abstract}

Simpulan penelitian ini adalah penggunaan media daring dapat membantu siswa dalam belajar passing atas melalui pembelajaran daring di SMAN 3 Pati

Kata kunci: Pembelajaran daring, hasil belajar, bola voli

PENDAHULUAN 
Pendidikan adalah usaha sadar dan berencana untuk mewujudkan suasana belajar dan proses pembelajaran agar peserta didik secara aktif mengembangkan spiritual keagamaan, pengendalian diri, kepribadian, kecerdasan, akhlak mulia, serta keterampilan yang diperlukan potensi dirinya (Juliyandi, 2015:103).

Pendidikan merupakan kewajiban yang harus dilaksanakan setiap warga negara. Pendidikan juga harus dilakukan sedini mungkin supaya dapat meningkatkan kualitas hidup dan ntuk memiliki kekuatan dirinya, masyarakat, bangsa dan negara (Ivanto, 2015:331).

Seperti yang tertuang pada Undang-undang RI No. 20 tahun 2003 tentang sistem pendidikan Nasional secara tegas Menyatakan bahwa pendidikan merupakan usaha sadar dan terencana untuk mewujudkan suasana belajar dan proses pembelajaran agar peserta didik secara aktif mengembangkan potensi dirinya untuk memiliki kekuatan spiritual keagamaan, pengendalian diri, kepribadian, kecerdasan, akhlak mulia, serta keterampilan yang diperlukan dirinya, masyarakat, bangsa dan Negara. Untuk mencapai tujuan pendidikan yang dimaksud, guru/ calon pendidik tidak hanya bisa mengedepankan instrument pengetahuan berkenaan dengan bidang studi atau ilmu semata, akan tetapi lebih jauh hendaknya dapat memahami konsep pendidikan yang menyeluruh, yaitu ilmu pendidikan (Indrajati, 2018:2).

Pendidikan jasmani olahraga dan kesehatan merupakan salah satu mata pelajaran yang dilaksanakan pada jenjang pendidikan dasar, menengah, bahkan pada pendidikan tinggi. Dalam pendidikan jasmani, olaharaga dan kesehatan merupakan media untuk mendorong pertumbuhan fisik, perkembangan psikis, keterampilan motorik, pengetahuan dan penalaran. Proses pembelajaran penjasorkes memberikan pengalaman belajar yang melibatkan proses mental dan fisik melalui interaksi antar siswa, siswa dengan guru, lingkungan dan sumber belajar lainnya (Ardhiansyah, 2014:723).

Pembelajaran merupakan aktualisasi kurikulum yang menuntut aktivitas, kreativitas, dan kearifan guru dalam menciptakan dan menumbuhkan kegiatan peserta didik sesuai dengan rencana yang telah diprogramkan secara efektif dan menyenangkan (Dana, 2015:3).

Dimasa pandemi Covid-19 ini, sebagian guru mengalami kesulitan dalam memberikan proses pembelajaran melalui media daring. Salah satunya guru penjasorkes yang biasanya meliputi 3 aspek selama pembelajaran daring ini hanya menggunakan aspek kognitif. Guru penjasorkes hanya memberikan teori saja melalui Whatsapp grup pada saat melakukan proses pembelajaran.

Pembelajaran daring online atau Pembelajaran Jarak Jauh bertujuan untuk memenuhi standar pendidikan dengan pemanfaatan teknologi informasi dengan menggunakan perangkat komputer atau gadget yang saling terhubung dengan siswa dan guru. Pembelajaran daring ini merupakan pembelajaran tanpa tatap muka secara langsung antar guru dan siswa, pembelajaran dilakukan melalui online, selama pembelajaran daring ini siswa merasa lebih sulit untuk memahami materi yang disampaikan oleh guru 
untuk pembelajaran daring (Sari, 2019:20).

Hasil belajar merupakan pencerminan tentang apa yang dicapai siswa setelah melakukan usaha. Tinggi rendahnya hasil belajar akan memberikan sumbangan dalam mencapai kesuksesan masa depan siswa. Hasil belajar adalah perubahan perilaku dan kemampuan secara keseluruhan yang dimiliki oleh siswa setelah belajar. Hasil belajar ada 3 aspek meliputi aspek kognitif, afektif, dan psikomotor (Irfan, 2019:428).

Berdasarkan observasi di SMAN 3 Pati pada tanggal 8 September 2020, kegiatan selama pembelajaran penjasorkes pada mata pelajaran bola voli yang dilakukan secara daring ini masih berjalan guru penjasorkes hanya menggunakan aspek kognitif hasil belajar siswa dari pengetahuan (kognitif) di kelas XI IPA 3. Pembelajaran daring ini membuat siswa kesulitan untuk memahami teori yang sudah diberikan pada siswa karena terbatasnya ruang dan waktu selama pembelajaran daring ini membuat hasil belajar siswa tidak maksimal karena hambatan di jaringan internet. Pada pembelajaran penjasorkes bola voli siswa kelas XI dengan kriteria ketuntasan minimum (KKM) 75, didapatkan bahwa selama pembelajaran daring siswa sulit memahami materi yang sudah diberikan.

Dengan melihat hasil data observasi, peneliti menyimpulkan bahwa hasil observasi pada mata pelajaran bola voli selama pembelajaran daring siswa kurang maksimal atau tidak berjalan dengan baik karena hanya didapatkan hasil 12 siswa yang mencapai kriteria ketuntasan minimum (KKM) dari jumlah total 36 siswa hal ini menunjukan bahwa $>50 \%$ siswa mengalami kesulitan.

Hasil belajar kognitif siswa di SMA N 3 Pati Analisis Pembelajaran Penjasorkes Melalui Media Daring Terhadap Hasil Belajar Kognitif Passing Atas Siswa di SMA N 3 Pati. Kegiatan pembelajaran yang tiba-tiba berubah akibat wabah virus corona (COVID-19), ini menjadi tantangan bagi sekolah dan guru khususnya guru penjasorkes yang biasanya menggunakan ranah 3 aspek. Namun pada saat ini, dengan berlakunya pembelajaran dirumah guru penjasorkes hanya menggunakan ranah aspek kognitif (pengetahuan) selama pembelajaran daring ini. Guru memberikan teori melalui whattsapp grup secara daring pada siswa, terdapat beberapa kendala dalam proses pembelajaran daring yang telah dilaksanakan ini. Tidak semua siswa mampu mengakses internet dan kurangnya siswa dalam penguasaan teori atau materi pada mata pelajaran penjasorkes yang disampaikan dengan guru melalui pembelajaran daring ini, terbatasnya akses internet di setiap daerah membuat siswa kesulitan dalam mengikuti pembelajaran daring ini. Hasil belajar dalam hasil belajar mempunyai peranan penting dalam proses pembelajaran hasil belajar digunakan untuk mengetahui kemampuan siswa dapat memahami serta mengerti materi tersebut. Proses belajar dinyatakan dalam simbol kalimat yang menjelaskan hasil yang sudah dicapai setiap siswa, kegiatan evaluasi yang bertujuan untuk mendapatkan data penilaian yang akan menunjukkan tingkat kemampuan siswa dalam mencapai tujuan pembelajaran.

Hasil belajar merupakan tolak ukur dari keberhasilan proses pembelajaran yang telah dilakukan. Pada umumya hasil belajar dilihat tiga aspek, yakni aspek kognitif, afektif dan 
psikomotorik. Secara garis besar, seorang siswa dikatakan berhasil mencapai tujuan pembelajaran jika menunjukkan perubahan pada aspek pengetahuan, sikap dan keterampilan menjadi lebih baik dari sebelumnya (Hadi, 2017:99)..

\section{METODE}

Penelitian ini menggunakan desain penelitian deskriptif kuantitatif dengan pendekatan One-Shot Case Study (Sugiyono, 2017:22), metode penelitian kuantitatif adalah metode penelitian yang berlandaskan pada filsafat positivisme untuk meneliti populasi atau sampel. One-Shot Case Study bertujuan untuk memperoleh data yang meyakinkan dan memberikan efek yang baik terhadap suatu variabel.

\section{Populasi dan Sampel}

Populasi dalam penelitian ini adalah siswa kelas XI di SMA N 3 PATI sebanyak 380 siswa, Tahun Pelajaran 2019/2020. Sampel pada penelitian ini adalah kelas XI IPA 3 dengan jumlah 36 siswa 1 kelas untuk dijadikan sample. Sampel yang digunakan kelas XI IPA 3, karena dari hasil observasi siswa kelas XI IPA 3 di SMA N 3 PATI, kelas XI kurang memahami materi dalam pembelajaran daring. Dengan demikian peneliti menggunakan sampel dalam penelitian ini berjumlah 36 siswa kelas XI IPA.

\section{Instrument Penelitian}

Soal tes dan Angket /kuesioner Teknik tes dalam penelitian ini berupa tes pilihan ganda. Tes tersebut digunakan untuk mengungkap aspek kognitif dengan mengetahui kemampuan siswa dalam melakukan materi passing atas melalui google form. Angket/kuesioner adalah sejumlah pernyataan tertulis yang digunakan untuk memperoleh informasi dari responden dalam arti laporan tentang pribadinya, atau hal-hal yang ia ketahui. Kuesioner atau angket merupakan suatu daftar yang berisi pertanyaan-pertanyaan yang harus dijawab atau dikerjakan oleh siswa yang ingin diselidiki, yang juga disebut responden (Yuli adi nugroho, 2011:42).

\section{Teknik Analisis Data}

Pada penelitian ini teknik analisis data yang digunakan adalah teknik analisis statistik menggunakan uji-t dengan bantuan analisis statistik data SPSS (Astuti Tri, 2013:192).

\section{HASIL DAN PEMBAHASAN}

\section{Data Hasil Pasing Atas}

Statistik Deskriptif

Tabel 1. Data Hasil Passing Atas

\begin{tabular}{|l|l|l|l|l|}
\hline \multirow{2}{*}{ Data Penelitian } & \multicolumn{2}{|c|}{ Mean } & Selisih & Kenaikan \\
\cline { 2 - 5 } & Pretest & Posttest & Ratrata & \\
\hline Hasil Belajar & 80.11 & 90 & 85.055 & $11 \%$ \\
\hline
\end{tabular}

Sumber: Data Penelitian 2021 
Berdasarkan tabel diatas, diketahui nilai rata-rata, standar deviasi, nilai maksimum, dan nilai maksimum untuk variabel pretest dan posttest kelas XI IPA 3. Berdasarkan tabel tersebut maka dapat diklasifikasikan kenaikan nilai dari pre-test ke post-test seperti pada tabel dibawah. Diketahui 36 siswa dikelas passing atas memiliki nilai Pre-Test 80.11. post-Test 90, selisih rata-rata 85.055 dan kenaikan sebesar $11 \%$.

Berikut adalah penyajian hasil belajar siswa pada kelas Passing atas

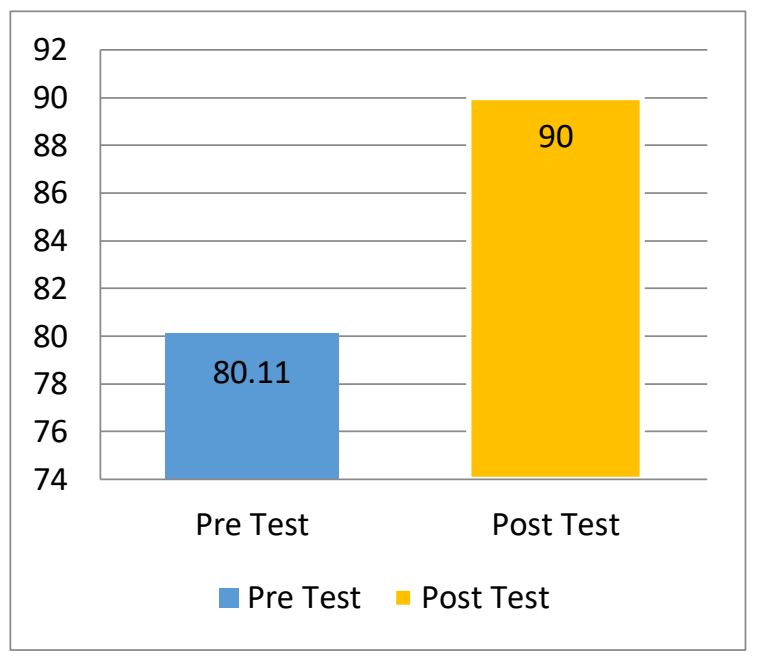

Gambar 1. grafik hasil belajar siswa

Grafik perbandingan hasil belajar passing atas yang meliputi rata-rata aspek kognitif.

Berdasarkan grafik perbandingan di atas, diketahui bahwa nilai naik secara signifikan.

Hasil Data Akhir

a) Uji Normalitas

Ho Kriteria Uji: Berdistribusi normal jika nilai sig.>0,5

Ha Kriteria Uji: Berdistribusi tidak normal jika nilai sig. $<0,5$

Tabel 2. Hasil Uji Normalitas

\begin{tabular}{|c|c|c|c|c|}
\hline \multirow{2}{*}{ Model } & \multicolumn{2}{|c|}{$\begin{array}{c}\text { Unstandardized } \\
\text { Residual }\end{array}$} & \multirow{2}{*}{$\begin{array}{c}\text { Test } \\
\text { Statistic }\end{array}$} & \multirow{2}{*}{ Sig. } \\
\hline & $\mathbf{N}$ & Std. Error & & \\
\hline $\begin{array}{l}\text { Hasil Uji } \\
\text { Normalitas }\end{array}$ & 36 & 5.933 & 0.095 & 0.672 \\
\hline
\end{tabular}

Sumber: Data Penelitian 2021 
Berdasarkan tabel di atas, diketahui bahwa seluruh variabel dalam penelitian memiliki distribusi yang normal, karena memiliki nilai sig. $>0,05$. Karena syarat data berdistribusi normal terpenuhi, maka dapat dilakukan uji t berpasangan (paired samples $t$ test).

b) Uji Homogenitas

Tabel 3. Uji Homogenitas

\begin{tabular}{|l|l|r|rr|}
\hline Data Hasil Uji Homogenitas & \multicolumn{1}{c|}{ df2 } & \multicolumn{2}{c|}{ Sig. } \\
\hline Post Test & Based on Mean & 27 & .056 \\
\cline { 2 - 5 } & Based on Median & 27 & .243 \\
\cline { 2 - 5 } & $\begin{array}{l}\text { Based on Median } \\
\text { and with adjusted df }\end{array}$ & 17.048 & .265 \\
\cline { 2 - 5 } & $\begin{array}{l}\text { Based on trimmed } \\
\text { mean }\end{array}$ & 27 & .058 \\
\hline
\end{tabular}

Sumber: Data Penelitian 2021

H0 : Varian sama atau homogen.

H1 : Varian tidak sama atau heterogen.

Taraf Signifikansi : $\mathrm{a}=5 \%=0.05$

Kriteria Pengujian : Data homogen jika nilai Sig. > 0.05

Berdasarkan tabel test of homogeneity of variances di ketahui nilai Sig. dari hasil belajar Passing Atas adalah: Hasil belajar Passing Atas based on mean : sig. 0.056

Berdasarkan tabel diatas, diketahui bahwa variabel dalam penelitian memiliki varian yang sama atau homogen, yaitu sig. .0.056 > 0.05 karena memiliki nilai Sig. >0.05. Maka dapat dikatakan bahwa Ho diterima sebagai keputusan bahwa data dinyatakan homogen dan dapat dilanjutkan denggan Uji-T

c) Uji t Test Berpasangan /Paired Sample t Test

Membandingkan nilai pretest dan posttest, dalam hal ini indikator penilaian adalah Kognitif Hipotesis

$H_{0}$ : Tidak ada perbedaan nilai pretest dan posttest siswa terhadap pembelajaran daring penjasorkes dan tidak mempengaruhi hasil belajar kognitif siswa.

(Saat pembelajaran daring siswa tidak efektif dalam meningkatkan passing atas karena tidak ada perbedaan nilai sebelum dan sesudah diberi pembelajaran daring)

$H_{1}$ : Ada perbedaan nilai pretest dan posttest siswa terhadap pembelajaran daring penjasorkes. 
(Saat pembelajaran daring siswa efektif dalam meningkatkan passing atas karena tidak ada perbedaan nilai sebelum dan sesudah diberi pembelajaran daring).

Kriteria Uji : Terima $H_{0}$ jika nilai Sig. $>0.05$

Tabel 4. Uji Paired Samples Test

\begin{tabular}{|c|c|c|c|c|c|}
\hline Model & Mean & $\begin{array}{l}\text { Std. } \\
\text { Deviation }\end{array}$ & $\begin{array}{l}\text { Std. } \\
\text { Error }\end{array}$ & $\begin{array}{l}\text { T } \\
\text { Hitung }\end{array}$ & $\begin{array}{l}\text { Sig. (2- } \\
\text { tailed) }\end{array}$ \\
\hline \begin{tabular}{l|l|}
1 & Pretest
\end{tabular} & 80.11 & 8.737 & 0.113 & 6.560 & 0.000 \\
\hline
\end{tabular}

Sumber: Data Penelitian 2021

Berdasarkan tabel diatas, diketahui bahwa nilai Sig. Adalah $0,000<0,05$ maka $H_{0}$ ditolak. Jadi dapat disimpulkan bahwa ada perbedaan nilai Pretest dan Posttest siswa kelas XI IPA 3 di SMAN 3 PATI atau dapat diartikan bahwa pembelajaran penjasorkes melalui daring dapat meningkatkan hasil passing atas karena ada perbedaan nilai sebelum dan sesudah, dimana rata-rata nilai sebelumnya adalah pretest 80.11 , posttest 90 , selisih rata-rata 85,055 , kenaikan sebesar $11 \%$.

\section{Pembahasan}

Penelitian ini bertujuan untuk menganalisa apakah pembelajaran penjasorkes melalui media daring pada masa Covid-19 ini dapat membantu siswa dalam meningkatkan hasil belajar kognitif. Berdasarkan hasil penelitian tersebut bahwa, siswa kelas XI IPA 3 SMAN 3 PATI dengan menggunakan materi passing atas. Adanya peningkatan hasil belajar yang signifikan, peningkatan tersebut diketahui dari rata-rata nilai awal passing atas (pretest) sebesar 80.11 dan nilai akhir (posttest) sebesar 90. Dari nilai tersebut mengalami peningkatan sebesar $11 \%$.

Hasil dari penelitian angket ini bertujuan untuk mengetahui gambaran pendapat siswa selama pembelajaran daring. Secara deskriptif dengan total 16 pernyataan terdiri dari 36 responden di kelas XI IPA 3. Hal ini dalam pembelajaran daring menunjukan bahwa, sebagian besar siswa ketika melakukan pembelajaran daring banyak kendala dalam jaringan internet. Pengisian angket atau kuesioner yang dilakukan secara online dengan memberikan link google form pada siswa melalui aplikasi whatsapp grup siswa mengisi link google form dirumahnya masing-masing.

Beberapa faktor keterkaitan yang dapat meningkatkan hasil belajar pada aspek kognitif passing atas siswa kelas XI IPA 3 SMAN 3 Pati diantarannya sebagai berikut: 
1. Diharapkan pembelajaran daring ini dapat membantu guru penjas untuk mengatasi siswa yang kesulitan dalam pembelajaran bola voli.

2. Siswa menjadi lebih aktif dalam menjalankan proses pembelajaran daring, tidak ada lagi siswa yang mengeluh untuk memahami pengetahuan (kognitif) dalam teknik passing atas bola voli.

3. Hasil penelitian ini sesuai dengan teori penelitian (Ali Sadikin, 2020:216) dengan judul Pembelajaran Daring di Tengah Wabah Covid-19. Penelitian ini bertujuan untuk mengetahui Apakah media daring dapat meningkatkan hasil belajar kognitif siswa kelas XI di SMAN 3 Pati. Dengan adanya pembelajaran daring ini semoga dapat membantu siswa lebih cepat memahami dan mampu memotivasi siswa yang kesulitan dalam pembelajaran daring dengan materi bola voli teknik passing atas.

4. Kelemahan penelitian ini menggunakan pendekatan One-Shot Case Study dimana dalam penelitian ini. Peneliti hanya menggunakan purposive sampling, karena situasi kondisi yang tidak memungkinkan

5. Peneliti juga memberikan solusi pada guru supaya pembelajaran yang digunakan selain menggunakan whatshapp grup yaitu menggunakan pembelajaran google classroom dan zoom supaya siswa lebih aktif dalam pembelajaran.

6. Peningkatan pembelajaran siswa terjadi karena adanya perlakuan yang diberikan peneliti kepada siswa sehingga dengan adanya sebelum di beri perlakuan dan sesudah diberi perlakuan menghasilkan peningkatan nilai yang signifikan oleh siswa.

Penelitian ini tidak lepas dari kekurangan ataupun yang menjadi kelebihan selama melakukan penelitian. Kekurangan dalam penelitian ini yaitu, pada saat melakukan penelitian siswa tidak dapat belajar secara bertatap muka langsung di sekolah karena terkendala kondisi pandemi. Yang mengakibatkan siswa melakukan pembelajaran dari rumah masing-masing sehingga penelitian ini dibuat dengan kondisi siswa melakukan dirumah masing-masing.

\section{KESIMPULAN}

Berdasarkan hasil penelitian pembahasan data tentang analisis pembelajaran penjasorkes melaui media daring terhadap hasil belajar kognitif passing atas siswa kelas XI di SMAN 3 PATI mengalami 
peningkatan, sehingga dapat disimpulkan bahwa penggunaan media daring pada siswa kelas XI IPA 3 di SMAN 3 Pati dapat membantu siswa dalam belajar. Pada pertemuan pertama yang menggunakan pretest mendapatkan hasil nilai rata-rata 80.11 dan pada pertemuan kedua yang menggunakan posttest mendapatkan hasil nilai rata-rata 90 yang termasuk kategori meningkat.

\section{DAFTAR PUSTAKA}

Ardhiansyah, F. (2014). Pengaruh Mental Imagery Terhadap Hasil Belajar Bola Basket Teknik Dasar Lay Up Dalam Pembelajaran Penjasorkes (Studi Pada Siswakelas Xi Sma Negeri 1 Kedungwaru Kabupaten Tulungagung). Jurnal Pendidikan Olahraga dan Kesehatan, 2(3).

Astuti, T., \& Mustikawati, R. I. (2013). Pengaruh persepsi nasabah tentang tingkat suku bunga, promosi dan kualitas pelayanan terhadap minat menabung nasabah. Nominal: Barometer Riset Akuntansi dan Manajemen, 2(1), 182-198.

Dana, P. Y. S., Tastra, I. D. K., \& Parmiti, D. P. (2015). Pengembangan Media Video Pembelajaran Penjasorkes Untuk Meningkatkan Hasil Belajar Siswa Kelas X Sman 1 Negara. Jurnal Edutech Undiksha, 3(1).

Hadi, S. (2017, May). Efektivitas Penggunaan Video Sebagai Media Pembelajaran Untuk Siswa Sekolah Dasar. In Seminar Nasional Teknologi Pembelajaran Dan Pendidikan Dasar 2017 (pp. 96-102).

Ivanto, R. E. (2015). Penerapan Model Pembelajaran Discovery Learning Pada Kurikulum 2013 Terhadap Hasil Belajar Passing Bawah (Studi Pada Siswa Kelas XI SMA Negeri 1 Tambakboyo Tuban). Jurnal Pendidikan Olahraga dan Kesehatan, 3(2).

Irfan, I. (2020). Peningkatan Hasil Belajar Siswa Pada Mata Pelajaran Penjasorkes Melalui Metode Drill Di Kelas X. Iik. 1 Man 2 Pasaman Barat. Jurnal Manajemen Pendidikan, $4(3), 427-436$.

Juliyandi, J., Saifuddin, S., \& Abdurrahman, A. (2015). Hubungan Motivasi Belajar dengan Hasil Belajar Pendidikan Jasmani Olahraga dan Kesehatan pada Siswa SMP Negeri 1 Lhoksukon Aceh Utara Tahun Pelajaran 2012/2013. Jurnal Ilmiah Mahasiswa Pendidikan Jasmani, Kesehatan dan Rekreasi, 1(2).

Nugroho, Y. A. (2011). Minat Siswa Terhadap Permainan Bola Voli Modifikasi dalam Pembelajaran Penjasorkes Pada Siswa Kelas VIII Di SMP 2 Kaliwiro Kab. Wonosobo (Doctoral dissertation, Universitas Negeri Semarang).

Setia Indrajati, B. I. M. A. (2017). Penerapan Pendekatan Taktis Untuk Meningkatkan Keterampilan Shooting Dalam Sepak Bola. Jurnal Pendidikan Olahraga dan Kesehatan, $6(1)$.

Sari, D. P., \& Sutapa, P. (2020, August). Efektivitas Pembelajaran Jarak Jauh Dengan Daring Selama Pandemi Covid-19 Mata Pelajaran Pendidikan Jasmani Olahraga Dan Kesehatan (Pjok). In Seminar Nasional Olahraga (Vol. 2, No. 1).

Sugiono, (2016). Metode Penelitian Pendidikan Pendekatan Kuantitatif, Kualitatif, Dan R\&D. Bandung: Alfabeta 